\title{
In silico Studies of Novel Synthetic Compounds as Potential Drugs to Inhibit Coronavirus (SARS-CoV-2): A Systematic Review
}

\author{
Viviane Amaral Porto ${ }^{1}$, , Ricardo Silva Porto ${ }^{2, *(\mathbb{D})}$ \\ Institute of Pharmaceutical Sciences, Federal University of Alagoas, Maceió, Brazil; vivianeportto@gmail.com (V.A.P.); \\ Institute of Chemistry and Biotechnology; Federal University of Alagoas, Maceió, Brazil; portto@iqb.ufal.br (R.S.P.); \\ Correspondence: portto@iqb.ufal.br (R.S.P.);
}

Scopus Author ID 8852139000

Received: 27.06.2021; Revised: 3.08.2021; Accepted: 6.08.2021; Published: 15.08.2021

\begin{abstract}
Severe Acute Respiratory Syndrome Coronavirus 2 (SARS-CoV-2), detected first in China, spread out fast to other parts of the world, and was soon recognized as a pandemic in March 2020. According to WHO, 179.686.071 confirmed cases and 3.899.172 deaths due to new coronavirus were reported worldwide on 26th June 2021. Despite countless efforts in searching for repositioned drugs to treat this disease, the results are still modest. Thus, the search for new molecular entities in the treatment of COVID-19 is an essential field in medicinal chemistry. Since the pandemic's beginning, several studies have reported the synthesis of novel organic compounds and their in silico interactions with the new coronavirus. Such computational studies are currently being applied to unveil the complexities of drug-target molecule interaction and also helping in developing new pharmacological treatments. This systematic review aims to provide an overview of studies describing the utilization of novel compounds as prospective drugs in the treatment of COVID-19.
\end{abstract}

Keywords: COVID-19; molecular docking; synthesis.

(C) 2021 by the authors. This article is an open-access article distributed under the terms and conditions of the Creative Commons Attribution (CC BY) license (https://creativecommons.org/licenses/by/4.0/).

\section{Introduction}

The COVID-19 has emerged as an infectious disease that spreads rapidly worldwide and is transmitted mainly by contact with contaminated saliva droplets or nasal discharge while the patient coughs or sneezes [1,2]. While efforts to develop pharmaceutical interventions for COVID-19 are underway, alternatives to avoid virus spread, such as social distancing and the use of masks, have been widely used and encouraged by the authorities [3]. Additionally, worldwide vaccination is still a challenge [4]. So far, no specific antiviral agent has been approved for the novel coronavirus, the causative agent of COVID-19, except for remdesivir [5]. This repositioned broad-spectrum RNA-dependent RNA polymerase inhibitor was recently approved against SARS-CoV-2 [6]. Drug repositioning works as an alternative and systematic method of drug discovery that can help determine new indications for existing drugs [7].

Novel synthetic compounds, sometimes referred to as new molecular entities (NME), are innovative molecules that serve previously unmet medical needs or significantly help advance patient care and public health $[8,9]$. NME has chemical structures that have never been approved before. Along with the drug repositioning approach, NME research is an essential branch in drug discovery and development. As a result, 378 new drugs and 27 biosimilars were approved by the US Food and Drug Administration (FDA) between 2010 and 2019 [10]. In the 
search for novel compounds, developing more economical and eco-friendly synthetic routes is highly significant $[11,12]$. In this context, increasingly cleaner reactions, ultrasound and microwave assistance, recoverable catalysts, and purification efficiency are desirable. Additionally, considering the industrial synthesis, reproducible and scaling-up chemical reactions are required.

In silico drug design techniques play a critical role in developing new drugs since they limit the use of animal models in clinical research and perform an economic identification of promising drug candidates [13]. Computational methods such as molecular docking generate ligand conformations and orientations so that the most appropriate ones are later selected for further interactions study in the protein binding site. Conversely, molecular dynamics help to predict the stability of a particular ligand [14]. In silico ADME predictions have also emerged as potential tools to predict drug absorption based on physicochemical and pharmacokinetic parameters [15]. Together, these computational approaches have been widely applied as additional tools in drug design and development.

The worldwide crisis generated by the pandemic associated with the lack of drugs for the treatment of COVID-19 contributed to the emergence of several studies aimed at synthesizing new compounds and their molecular interaction with the coronavirus proteins by computational tools. The present systematic review aims to provide an overview of these studies since some of them may soon reveal new chemical entities to treat this global disease.

\section{Material and Methods}

A systematic review was performed through a literature search conducted in June 2021 and included articles published and indexed from 01/01/2020 to 06/10/2021. This literature search was carried out over specialized search databases (PubMed, SCOPUS, and SciFinder) using distinct combinations of the following keywords: synthesis, coronavirus, COVID-19, and docking. Search terms were selected based on our aim to find everything published about molecular docking interactions of synthetic compounds with coronavirus proteins, given that molecular docking may be considered the most used tool in drug development. Parameters of inclusion criteria were defined as follows: 1. Articles written in English; 2. Studies describing molecular docking interaction of novel synthetic compounds; 3 . Studies describing molecular dynamics or ADME/T predictions. Articles were excluded with the following properties: 1 . Studies are reporting drugs against targets other than the new coronavirus; 2 . Studies describing metal complexes preparation and; 3. Studies not describing conventional synthesis (e.g., combinatorial synthesis, polymer synthesis).

For the manuscript choices, articles were selected according to the title, then to abstract, and then through an analysis of the full-text publication. Finally, the resulting papers were manually reviewed to identify and exclude the works as stated in the criteria described above.

\section{Results}

The primary search resulted in 1155 articles, of which 797 remained after the removal of duplicates (Figure 1). Overall, 60 studies fitted the inclusion criteria. Then, the full text of each article was reviewed. Articles that matched the exclusion criteria were withdrawn from the study, resulting in 25 original articles describing newly synthesized molecules through conventional synthetic routes and their molecular docking interactions with the new coronavirus proteins. 
As we can see in table 1, different classes of compounds, targets, software for molecular docking, and additional paper features are described. Concerning compound classes, the great majority of the studies $(68 \%)$ describe nitrogen heterocyclic synthesis. Despite the classification shown in the table, most of the synthesized compounds are hybrid or multifunctional compounds. With regard to targets, the main protease was the compound's target is $76 \%$ of the studies, followed by nucleocapsid protein and RNA polymerase (16\% and $12 \%$, respectively). Furthermore, $84 \%$ of the studies explored compounds as mono-target drug candidates, while $16 \%$ evaluated them as potential multi-target drugs. Molecular docking interactions were mainly accomplished by Autodock vina, representing 56\% of the studies.

Additional features of the selected articles are presented in table 1. Although we did not consider these features in the initial search, they can indicate studies' quality assessment. ADME/T predictions were evaluated in $40 \%$ of the studies. In $32 \%$ of the studies, an X-ray crystal structure was obtained and analyzed. The same percentage was observed for studies that appraised density functional theory (DFT). In addition, 20\% of the studies accomplished molecular dynamics simulations. Finally, sonochemical synthesis was performed in $16 \%$ of the studies.

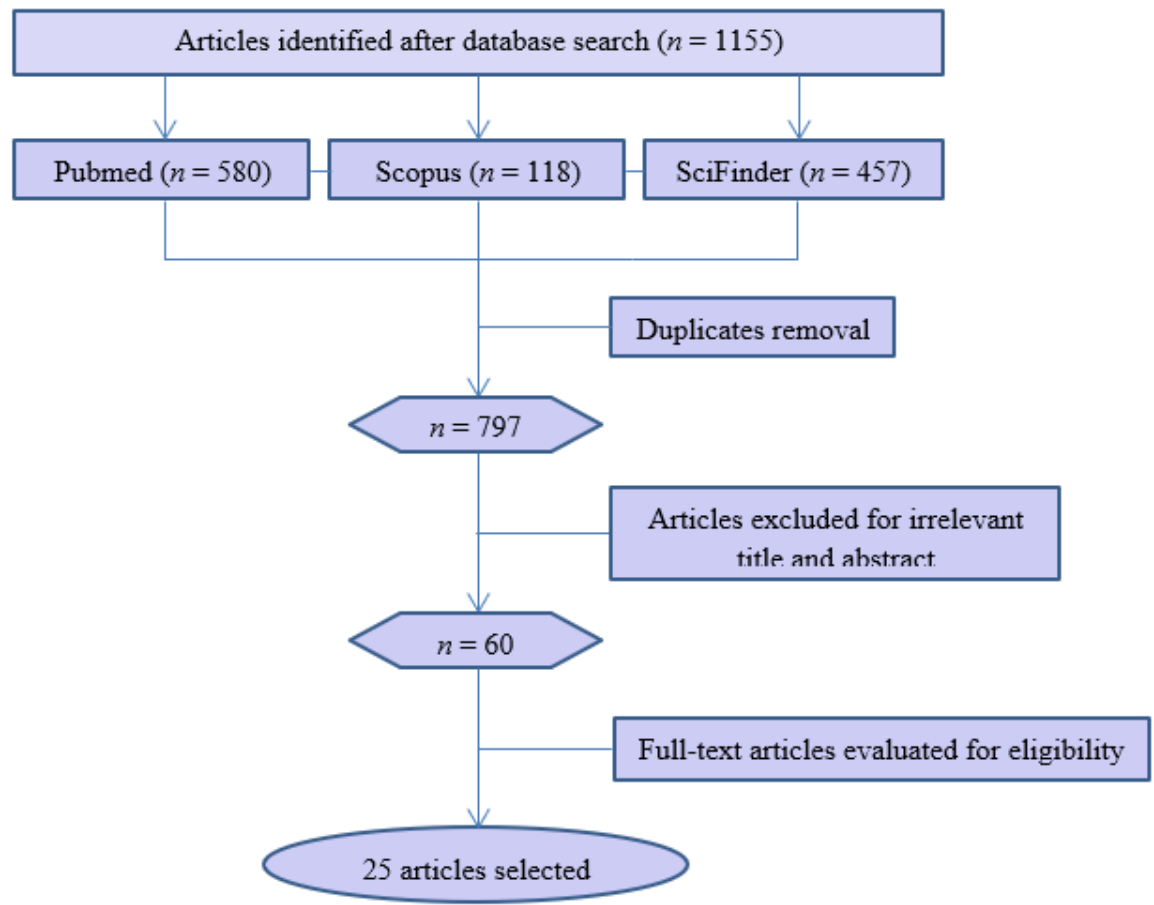

Figure 1. Study selection diagram.

Table 1. Characteristics of studies included in the systematic review.

\begin{tabular}{|c|c|c|c|c|}
\hline Study & Compound Class & Target (PDB ID) & Software & Additional Features \\
\hline $\begin{array}{c}\text { Abu-Melha et al., } \\
2020[16]\end{array}$ & triazolopyrimidine & Main protease (6Y84) & AutoDock Vina & $\begin{array}{c}\text { Clean Grinding Technique \& } \\
\text { Molecular Dynamics }\end{array}$ \\
\hline $\begin{array}{c}\text { Ahmed- } \\
\text { Belkacem et al., } \\
2020 \text { [17] }\end{array}$ & $\begin{array}{c}\text { adenine } \\
\text { dinucleosides }\end{array}$ & Nsp14 (5C8T \& 5NFY) & Autodock Vina & in vitro evaluation \\
\hline $\begin{array}{l}\text { Alsafi et al., } \\
2020[18]\end{array}$ & chalcone & Main protease (7BYQ) & Autodock Vina & $\begin{array}{c}\text { X-ray crystal structure } \\
\text { analysis }\end{array}$ \\
\hline $\begin{array}{l}\text { Alshammari et } \\
\text { al., } 2021 \text { [19] }\end{array}$ & $\begin{array}{c}\text { quinolonyl } \\
\text { acetohydrazides }\end{array}$ & $\begin{array}{c}\text { Main protease (6LU7) } \\
\text { RNA polymerase } \\
(6 \mathrm{M} 71) \\
\end{array}$ & Autodock 4.2 & $\begin{array}{l}\text { NMR, mass, IR \& elemental } \\
\text { analysis characterization }\end{array}$ \\
\hline $\begin{array}{c}\text { Aly et al., } 2021 \\
{[20]}\end{array}$ & bis-quinolinones & Main protease (6LU7) & AutoDock 4.2 & $\begin{array}{c}\text { X-ray crystal structure } \\
\text { analysis }\end{array}$ \\
\hline $\begin{array}{c}\text { Asha et al., } 2021 \\
{[21]}\end{array}$ & piperidines & $\begin{array}{c}\text { Spike (6VSB) } \\
\text { Main protease (6Y84) }\end{array}$ & AutoDock Vina & $\begin{array}{l}\text { X-ray crystal structure } \\
\text { analysis, DFT studies \& } \\
\text { ADMET predictions }\end{array}$ \\
\hline
\end{tabular}




\begin{tabular}{|c|c|c|c|c|}
\hline Study & Compound Class & Target (PDB ID) & Software & Additional Features \\
\hline $\begin{array}{c}\text { Benbouguerra et } \\
a l ., 2021[22]\end{array}$ & $\begin{array}{c}\text { Hydrazino- } \\
\text { phosphonic acid }\end{array}$ & $\begin{array}{c}\text { Main protease }(6 \mathrm{LU} 7) \\
\text { RNA polymerase } \\
(7 \mathrm{BV} 2)\end{array}$ & Autodock 4.2 & $\begin{array}{l}\text { one-pot multicomponent } \\
\text { reaction, DFT \& Spectral } \\
\text { studies }\end{array}$ \\
\hline $\begin{array}{l}\text { Chemboli et al., } \\
2021 \text { [23] }\end{array}$ & quinoxalines & Nucleocapsid (6M3M) & $\begin{array}{l}\text { GemDock } \\
\text { DockThor } \\
\text { SwissDock }\end{array}$ & $\begin{array}{l}\text { Sonochemical synthesis, in } \\
\text { vitro evaluation \& ADMET } \\
\text { predictions }\end{array}$ \\
\hline $\begin{array}{l}\text { Chhetri et al., } \\
2021[24,25]\end{array}$ & Azo-imidazoles & Main protease (6LU7) & Autodock Vina & $\begin{array}{l}\text { ADME predictions, NMR \& } \\
\text { IR characterization }\end{array}$ \\
\hline $\begin{array}{c}\text { Chidambaram et } \\
\text { al., } 2021 \text { [26] }\end{array}$ & coumarins & Main protease $(5 \mathrm{~N} 5 \mathrm{O})$ & Autodock Vina & $\begin{array}{c}\text { ADME predictions, NMR, } \\
\text { mass, IR \& elemental analysis } \\
\text { characterization }\end{array}$ \\
\hline $\begin{array}{l}\text { Domínguez-Villa } \\
\text { et al., 2021 [27] }\end{array}$ & indolones & Main protease (6LU7) & Autodock tools & ADMET predictions \\
\hline $\begin{array}{l}\text { Douche et al., } \\
2021[28]\end{array}$ & quinolinols & Main protease (6Y84) & AutoDock Vina & $\begin{array}{l}\text { X-ray crystal structure } \\
\text { analysis \& DFT studies }\end{array}$ \\
\hline $\begin{array}{c}\text { Kalai et al., } 2021 \\
\text { [29] }\end{array}$ & Pyridazinone & $\begin{array}{l}\text { Nsp3 (6WEY), Main } \\
\text { protease (6XHU), } \\
\text { Papain-like protease } \\
\text { (6YVA), Nucleocapsid } \\
\text { (6WKP), Co-factor } \\
\text { Complex (6WQD) }\end{array}$ & SwissDock & $\begin{array}{l}\text { X-ray crystal structure } \\
\text { analysis, DFT studies \& } \\
\text { TGA/DTA studies }\end{array}$ \\
\hline $\begin{array}{l}\text { Khorsandi et al., } \\
2021[30]\end{array}$ & Lopinavir analogs & Main protease (6LU7) & AutoDock 4.2 & $\begin{array}{l}\text { Hoveyda-Grubbs' catalyst } \\
\text { Molecular Dynamics }\end{array}$ \\
\hline $\begin{array}{l}\text { Kreutzer } \text { et al., } \\
\quad 2020[31]\end{array}$ & cyclic peptide & Main protease (6YB7) & AutoDock Vina & $\begin{array}{l}\text { Solid phase synthesis } \\
\text { in vitro evaluation \& } \\
\text { Molecular Dynamics }\end{array}$ \\
\hline $\begin{array}{l}\text { Kusumaningsih } \\
\text { et al., 2021 [32] }\end{array}$ & phloroglucinol & Main protease (6LU7) & $\begin{array}{l}\text { AutoDock } \\
\text { wizard }\end{array}$ & $\begin{array}{l}\text { Sonochemical synthesis, DFT } \\
\text { studies \& ADMET predictions }\end{array}$ \\
\hline $\begin{array}{c}\text { Lauro et al., } 2021 \\
{[33]}\end{array}$ & Lactam-Steroid & Main protease (6LU7) & $\begin{array}{c}\text { Chimera } \\
\text { Achilles-Blind }\end{array}$ & $\begin{array}{l}\text { Mild conditions synthesis \& } \\
\text { NMR characterization }\end{array}$ \\
\hline $\begin{array}{l}\text { Özkan et al., } \\
2020 \text { [34] }\end{array}$ & Norcantharimides & Main protease (6LU7) & Molegro & $\begin{array}{c}\text { ADME predictions, NMR, IR } \\
\text { \& elemental analysis } \\
\text { characterization }\end{array}$ \\
\hline $\begin{array}{l}\text { Sarfraz et al., } \\
2021 \text { [35] }\end{array}$ & thiobarbituric acids & $\begin{array}{c}\text { Main protease (6Y84, } \\
\text { 6LU7) }\end{array}$ & Autodock tools & $\begin{array}{l}\text { one-pot multicomponent } \\
\text { reaction } \\
\text { Molecular Dynamics \& } \\
\text { ADMET predictions } \\
\end{array}$ \\
\hline $\begin{array}{c}\text { Satyanarayana et } \\
a l ., 2021[36] \\
\end{array}$ & pyrazines & Nucleocapsid (6M3M) & Autodock Vina & $\begin{array}{c}\text { Sonochemical synthesis \& } \\
\text { ADME predictions }\end{array}$ \\
\hline $\begin{array}{c}\text { Shahinshavali et } \\
\text { al., 2020 [37] }\end{array}$ & quinoxalines & Nucleocapsid (6M3M) & AutoDock Vina & Sonochemical synthesis \\
\hline $\begin{array}{c}\text { Topal et al., } 2021 \\
{[38]}\end{array}$ & hydrazone-pyridine & Main protease (6LU7) & AutoDock Vina & $\begin{array}{c}\text { X-ray crystal structure } \\
\text { analysis, DFT studies, IR \& } \\
\text { Raman spectroscopic analysis }\end{array}$ \\
\hline $\begin{array}{l}\text { Venkateshan } \text { et } \\
\text { al., 2020 [39] }\end{array}$ & Azaphenantherenes & Main protease (6LU7) & AutoDock Vina & $\begin{array}{c}\text { X-ray crystal structure } \\
\text { analysis, DFT studies \& } \\
\text { QTAIM analysis }\end{array}$ \\
\hline $\begin{array}{l}\text { Venkateshan et } \\
\text { al., } 2020[40]\end{array}$ & Azafluorenes & $\begin{array}{l}\text { RNA polymerase } \\
\text { (6NUR) }\end{array}$ & AutoDock Vina & $\begin{array}{l}\text { X-ray crystal structure } \\
\text { analysis, DFT studies, } \\
\text { ADMET predictions \& } \\
\text { binding free energy } \\
\text { calculations }\end{array}$ \\
\hline
\end{tabular}

\section{Discussion}

\subsection{Synthesis.}

The emergence of new diseases and the increase in the incidence of those already known aroused the interest of researchers in the development and synthesis of new pharmacologically active substances [41,42]. For example, regarding the new coronavirus pandemic, in addition to the importance of worldwide vaccination and the repositioning of 
existing drugs, the synthesis of new potential drug candidates in the treatment of COVID-19 is highly relevant $[43,44]$.

In general, studies included in this review use conventional chemical reactions and short synthetic routes, with moderate to high overall yields. One-pot multicomponent reactions were applied as well $[22,35]$. It is an excellent tool for rapidly generating small molecules with broad chemical diversity and molecular complexity [45].

As ultrasound irradiation has dramatically accelerated organic reactions, sonochemical synthesis has gained considerable attention in recent years [46], and diverse transformations have been performed using ultrasound [47,48]. For example, Kusumaningsih et al. prepared dimeric 2,4-diacetyl phloroglucinol in a $95 \%$ yield after sonication for $30 \mathrm{~min}$ at $60^{\circ}$ [32]. The same reaction, utilizing conventional stirring, yielded the product in $87 \%$ after 3 hours. The gram-scale synthesis was also efficient under ultrasound irradiation, providing the phloroglucinol derivative in $94 \%$ after 20 min of reaction. Under optimized conditions, quinoxaline derivatives [22, 37] and pyrazine derivatives [36] were prepared using an ultrasound-assisted methodology. Compared to their previously reported synthesis, the new sonochemical method was performed in shorter times and avoided using solvents that are not environmentally friendly.

Progress in solid-phase synthesis has stimulated great interest in protein design and synthesis of structurally diverse peptide libraries that can be screened against biological targets. Kreutzer et al. designed and synthesized a cyclic peptide containing a [4-(2aminoethyl)phenyl]-acetic acid (AEPA) linker, named UCI-1, by FMOC-based solid synthesis [31]. Treatment of the Fmoc-AEPA-OH intermediate with 2-chlorotrityl chloride resin followed by linear peptide synthesis and resin cleavage provided the desired cyclic peptide used by authors for in vitro and in silico studies. The Grindstone technique has also been used as a green and fast process to synthesize organic compounds [49]. This method, first used by Toda [50], has proven that different reactions can be performed in high yield by grinding solids together using a mortar and pestle. Abu-Melha et al. prepared some triazolopyrimidine derivatives by grinding precursor reagents in the presence of a few drops of acetic acid at room temperature [15]. The products were obtained in 88-92\% yield. Chidambaram et al. synthesized some coumarin analogs through a grinding technique, in which the reagents were placed in the ground well, and few drops of concentrated $\mathrm{HCl}$ were added [51]. In this case, yields varied from $82-92 \%$.

\subsection{Computational studies.}

Molecular docking is a computational method that predicts the preferred binding position of a molecule into the binding site of a macromolecular target. In addition, it indicates the strength of the connection or binding affinity between the ligand and protein by using scoring functions. Molecular docking has been widely employed as an essential tool in drug design and development [52].

As mentioned before, the main protease $\left(\mathrm{M}^{\mathrm{PRO}}\right)$ from SARS-CoV-2 was the primary target for molecular docking in $76 \%$ of the studies (19 studies) described here. This protease is essential for processing polyproteins translated from virus RNA and critical for virus replicating and spreading [53]. Recent studies have shown that $\mathrm{M}^{\mathrm{PRO}}$ of SARS-CoV-2 consisted of three domains, and similar to other coronaviruses, SARS-CoV-2 $\mathrm{M}^{\mathrm{PRO}}$ also has a catalytic Cys-145-His-41 dyad located in a groove between domain I and domain II [54]. Table 2 shows the docking scores of selected compounds with SARS-CoV-2 $\mathrm{M}^{\mathrm{PRO}}$. From the table, 
we can notice that all the docked compounds were promising in binding to the $\mathrm{M}^{\mathrm{PRO}}$, with higher docking scores than reference drugs. Furthermore, most compounds successfully interacted with the $\mathrm{M}^{\mathrm{PRO}}$ catalytic dyad or at least one amino acid. They thus showed auspicious protease activity, thereby being attractive drug candidates for the new coronavirus.

The nucleocapsid protein is a relevant structural protein for the coronavirus, which participates in the RNA package and virus particle delivery [55]. It is, therefore, a potential target for antiviral drugs and was the unique target in 3 studies [23, 36, 37] (Table 1). Pyrrolo[2,3-b]-quinoxaline [8] and 3-alkynyl substituted 2-chloroquinoxaline derivatives [37] were docked against the $N$-terminal RNA binding domain. In both studies, the novel synthetic compounds showed greater binding affinity than reference compound DA-3003-1. In addition, 2-alkynyl 3-chloropyrazines prepared by Satyanarayana et al. [36] also presented good docking scores when targeted the nucleocapsid of SARS-CoV-2. In this case, binding affinities were lower than DA-3003-1 but higher than favipiravir.

Potential multi-target drugs are more advantageous than mono-target ones in better pharmacokinetics prediction and reduced risk of drug synergism [7]. Only 4 studies (16\% of the studies) evaluated the novel synthetic compounds as multi-target potential drugs $[19,21$, $22,29]$. In this regard, we can mention the work of Kalay et al. [29]. These authors prepared a novel synthetic styrylpyridazin-3(2H)-one, considered a promising candidate for multi-target therapy. From the 7 targets assessed, 5 presented negative binding affinity values. These include nsp3 macro $\mathrm{X}$ domain, main protease, papain-like protease, nucleocapsid, and the cofactor complex between nsp7 and the C-terminal domain of nsp8.

Molecular Dynamics (MD) is the most widely used computational technique to study biological systems' equilibration structures and dynamic interactions [56,57]. It simulates the dynamic behavior of molecular systems as a function of time, treating all the entities in the simulation box as flexibles. 4 studies (16\% of the studies) used MD simulation to monitor and evaluate the conformational behaviors of the atoms and molecules, to validate the outcomes of the molecular docking $[15,30,31,35]$. The RMSD profile results showed that, in these studies, selected compounds exhibited significant stability in the active site during MD simulations.

Aside from previously discussed pharmacodynamic properties, effective and safe medications displayed favorable pharmacokinetics that combines adequate absorption, distribution, metabolism, excretion, as well as tolerable toxicity (ADMET). Costly drug failures are found in late development or clinical trials due to poor pharmacokinetics and toxicity issues. 9 out of 25 studies performed ADME/T predictions for the synthesized compounds [21, 23-27, 32, 34-36, 40]. Tools such as SwissADME [58], admetSAR [59] and pkCSM-pharmacokinetics [60] were used to calculate this predictive parameters. Most of these studies describe amine-containing compounds. Because they are weak bases, amines respond to balancing the dual requirements of water and fat solubility. By having a pKa value in the range of 6-8, they are partially ionized at the slightly acidic and alkaline pHs present in the gut and blood, respectively. They can easily balance their ionized and non-ionized forms, allowing them to cross cell membranes in the unionized form.

In contrast, the presence of the ionized form gives the molecule good water solubility and allows good binding interactions with its target link site [61]. Thus, with few exceptions, the compounds showed good drug-likeness properties, with no Lipinksi or Veber rules violations. Where applicable, the molecules also appeared to be safe from the standpoint of predicted acute and chronic toxicities. 
Table 2. Docking scores of selected compounds with SARS-CoV-2 $\mathrm{M}^{\mathrm{PRO}}$.

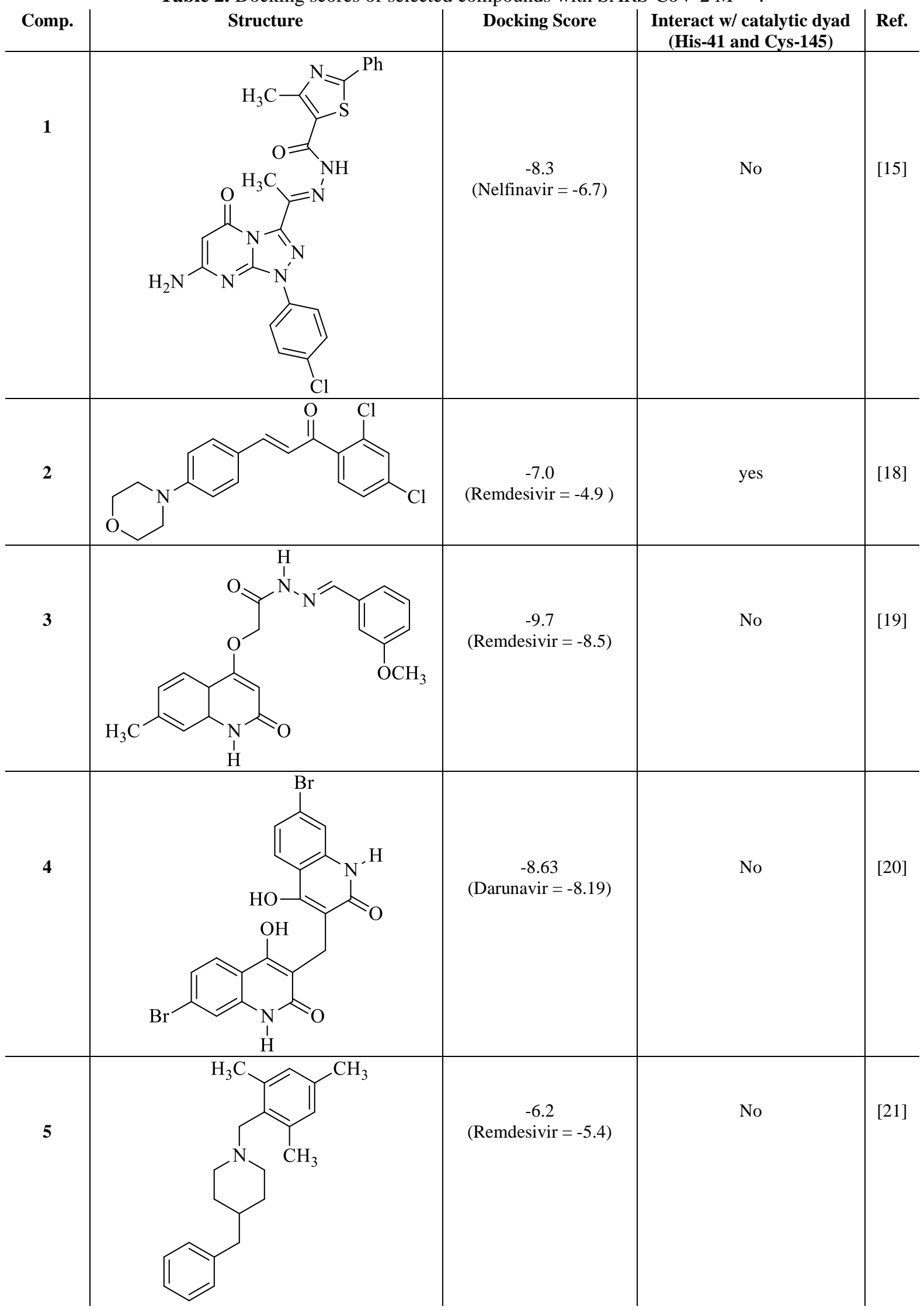




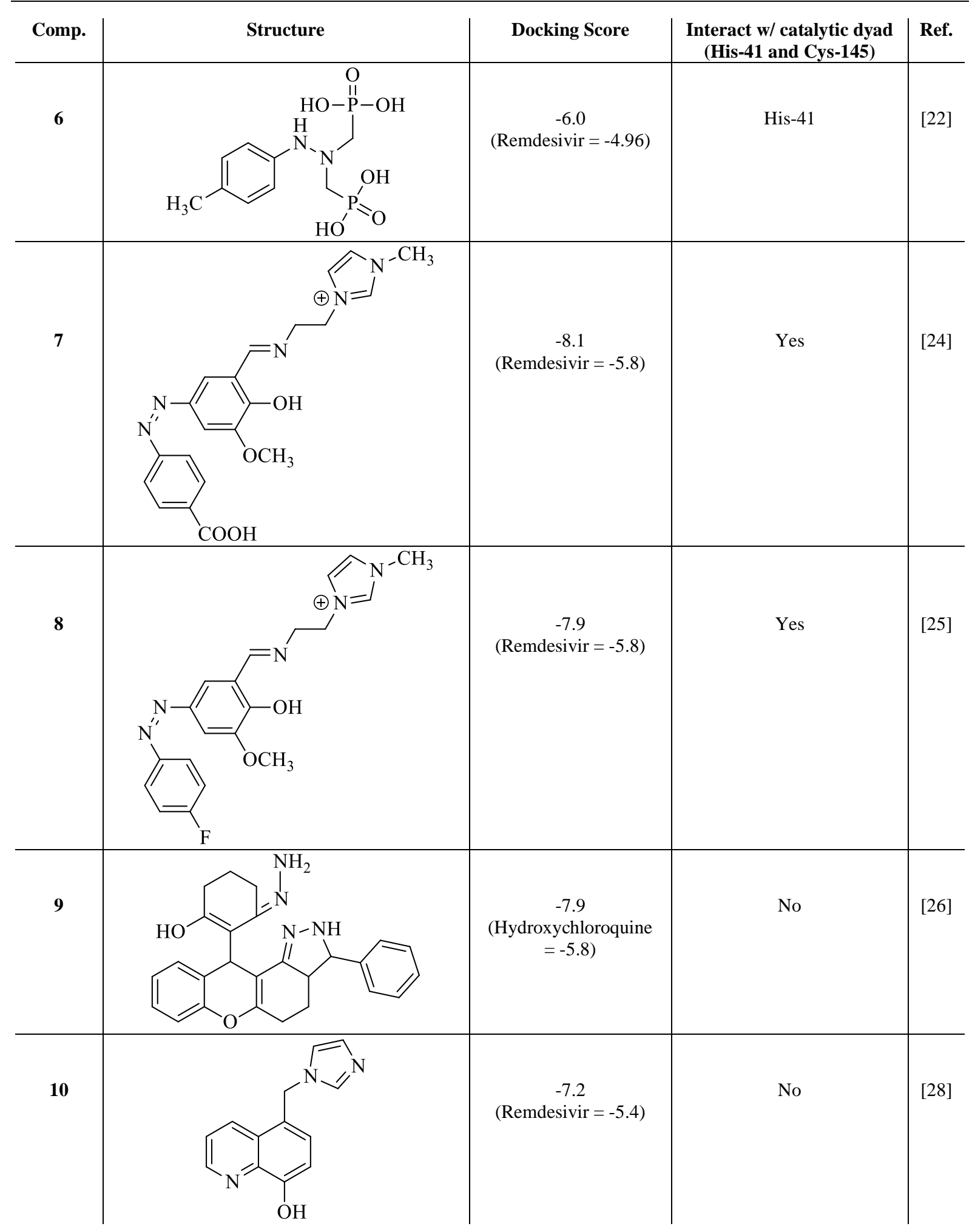




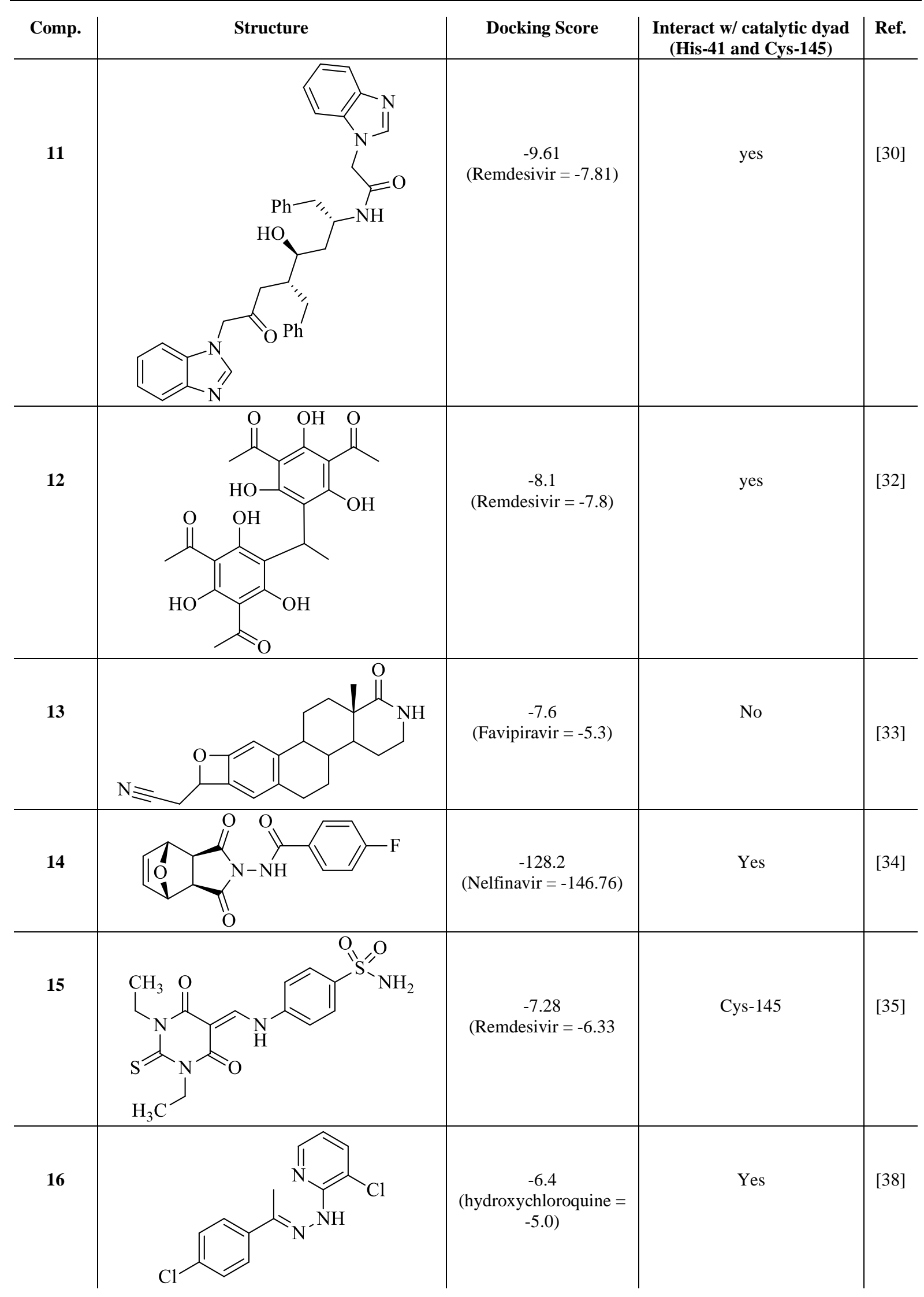




\begin{tabular}{l|l|c|c|c|}
\hline Comp. & Docking Score & $\begin{array}{c}\text { Interact w/ catalytic dyad } \\
\text { (His-41 and Cys-145) }\end{array}$ & Ref. \\
\hline (Remdesivir $=-8.5)$ & No & \\
\hline
\end{tabular}

\section{Conclusions}

This review has considered the perspectives in applying novel synthetic compounds as potential drugs in treating COVID-19 disease. Computational methods such as molecular docking, molecular dynamics, and ADME/T predictions have been demonstrated as useful for pharmacodynamics and pharmacokinetics evaluations. As most synthetic strategies use classical and well-studied organic reactions, this approach can contribute to the rapid development of new drugs to treat this pandemic respiratory disease that has devastated many lives. Despite significant improvements described here, it is essential to mention that synthesis optimization in large-scale and clinical tests will be crucial to develop a new and efficient drug to treat COVID-19.

\section{Funding}

This research received no external funding.

\section{Acknowledgments}

The authors acknowledge CACTVS Instituição de Pagamento S.A. for fellowships to V.A.P.

\section{Conflicts of Interest}

The authors declare no conflict of interest.

\section{References}

1. Park, M.; Cook, A. R.; Lim, J. T.; Sun, Y.; Dickens, B. L. A systematic review of COVID-19 epidemiology based on current evidence. Journal of clinical medicine 2020, 9, 967, https://doi.org/10.3390/jcm9040967.

2. Esakandari, H.; Nabi-Afjadi, M.; Fakkari-Afjadi, J.; Farahmandian, N.; Miresmaeili, S. M.; Bahreini, E. A comprehensive review of COVID-19 characteristics. Biological procedures online 2020, 22, 1-10, https://doi.org/10.1186/s12575-020-00128-2.

3. Kaur, S.; Bherwani, H.; Gulia, S.; Vijay, R.; Kumar, R. Understanding COVID-19 transmission, health impacts and mitigation: timely social distancing is the key. Environment, Development and Sustainability 2021, 23, 6681-6697, https://doi.org/10.1007/s10668-020-00884-x.

4. Wouters, O. J.; Shadlen, K. C.; Salcher-Konrad, M.; Pollard, A. J.; Larson, H. J.; Teerawattananon, Y., \& Jit, M. Challenges in ensuring global access to COVID-19 vaccines: production, affordability, allocation, and deployment. The Lancet 2021, 397, 1023-1034, https://doi.org/10.1016/S0140-6736(21)00306-8.

5. Sun, D. Remdesivir for treatment of COVID-19: combination of pulmonary and IV administration may offer aditional benefit. The AAPS journal 2020, 22, 1-6, https://doi.org/10.1208/s12248-020-00459-8.

6. Young, B.; Tan, T. T.; Leo, Y. S. The place for remdesivir in COVID-19 treatment. The Lancet. Infectious Diseases 2021, 21, 20, https://doi.org/10.1016/S1473-3099(20)30911-7. 
7. Mohamed, K.; Yazdanpanah, N.; Saghazadeh, A.; Rezaei, N. Computational drug discovery and repurposing for the treatment of COVID-19: a systematic review. Bioorganic chemistry 2021, 106, 104490, https://doi.org/10.1016/j.bioorg.2020.104490.

8. Camp, J. R.; Fuhs, J. V.; Beattie, S. D.; Asay, R. L.; Hoffman, R. D. Review of the Food and Drug Administration's Center for Drug Evaluation and Research Program for New Molecular Entities: Trends and Regulatory Requirements in Acknowledgment Letters and Filing Communications. Therapeutic Innovation \& Regulatory Science 2021, 1-15, https://doi.org/10.1007/s43441-020-00253-w.

9. Agarwal, S.; Chinn, L.; Zhang, L. An overview of transporter information in package inserts of recently approved new molecular entities. Pharmaceutical research 2013, 30, 899-910, https://doi.org/10.1007/s11095-012-0924-0.

10. Brown, D. G.; Wobst, H. J. A Decade of FDA-Approved Drugs (2010-2019): Trends and Future $\begin{array}{lllll}\text { Directions. Journal } \quad \text { of } \quad \text { Medicinal } & \text { Chemistry 2020, }\end{array}$ https://doi.org/10.1021/acs.jmedchem.0c01516.

11. Cahiez, G.; Moyeux, A.; Cossy, J. Grignard Reagents and Non-precious Metals: Cheap and Eco-Friendly Reagents for Developing Industrial Cross-Couplings. A Personal Account. Advanced Synthesis \& Catalysis 2015, 357, 1983-1989, https://doi.org/10.1002/adsc.201400654.

12. Poomathi, N.; Perumal, P. T.; Ramakrishna, S. An efficient and eco-friendly synthesis of 2-pyridones and functionalized azaxanthone frameworks via indium triflate catalyzed domino reaction. Green Chemistry 2017, 19, 2524-2529, https://doi.org/10.1039/c6gc03440c.

13. Brogi, S.; Ramalho, T. C.; Kuca, K.; Medina-Franco, J. L.; Valko, M. In silico Methods for Drug Design and Discovery. Frontiers in Chemistry 2020, 8, 612, https://doi.org/10.3389/fchem.2020.00612.

14. Al-Obaidi, Z.; Rasheed, O. F. A.; Mahdi, M. F.; Raauf, A. M. R. In Silico Design, Synthesis and Characterization of New Spebrutinib Analogues. Pharm Anal Acta 2019, 10, 612, https://doi.org/10.35248/2153-2435.19.10.612.

15. Sun, H.; Scott, D. O. Structure-based drug metabolism predictions for drug design. Chemical biology \& drug design 2010, 75, 3-17, https://doi.org/10.1111/j.1747-0285.2009.00899.x.

16. Abu-Melha, S.; Edrees, M. M.; Riyadh, S. M.; Abdelaziz, M. R.; Elfiky, A. A.; Gomha, S. M. Clean Grinding Technique: A Facile Synthesis and In Silico Antiviral Activity of Hydrazones, Pyrazoles, and Pyrazines Bearing Thiazole Moiety against SARS-CoV-2 Main Protease (Mpro). Molecules 2020, 25, 4565, https://doi.org/10.3390/molecules25194565 .

17. Ahmed-Belkacem, R.; Sutto-Ortiz, P.; Guiraud, M.; Canard, B.; Vasseur, J. J.; Decroly, E.; Debart, F. Synthesis of adenine dinucleosides SAM analogs as specific inhibitors of SARS-CoV nsp14 RNA cap guanine-N7-methyltransferase. European journal of medicinal chemistry 2020, 201, 112557, https://doi.org/10.1016/j.ejmech.2020.112557.

18. Alsafi, M. A.; Hughes, D. L.; Said, M. A. First COVID-19 molecular docking with a chalcone-based compound: synthesis, single-crystal structure and Hirshfeld surface analysis study. Acta Crystallographica Section C: Structural Chemistry 2020, 76, https://doi.org/10.1107/S2053229620014217.

19. Alshammari, M. B.; Ramadan, M.; Aly, A. A.; El-Sheref, E. M.; Bakht, M. A.; Ibrahim, M. A.; Shawky, A. M. Synthesis of potentially new schiff bases of N-substituted-2-quinolonylacetohydrazides as anti-COVID19 agents. Journal of molecular structure 2021, $1230, \quad 129649$, https://doi.org/10.1016/j.molstruc.2020.129649.

20. Aly, A. A.; Hassan, A. A.; Mohamed, A. H.; Osman, E. M.; Bräse, S.; Nieger, M., Ibrahim, M. A. A.; Mostafa, S. M. Synthesis of 3, 3'-methylenebis (4-hydroxyquinolin-2 (1 H)-ones) of prospective anti-COVID-19 drugs. Molecular diversity 2021, 25, 461-471, https://doi.org/10.1007/s11030-020-10140-z.

21. Asha, R. N.; Nayagam, B. R. D.; Bhuvanesh, N. Synthesis, molecular docking, and in silico ADMET studies of 4-benzyl-1-(2, 4, 6-trimethyl-benzyl)-piperidine: Potential Inhibitor of SARS-CoV2. Bioorganic chemistry 2021, 112, 104967, https://doi.org/10.1016/j.bioorg.2021.104967.

22. Benbouguerra, K.; Chafai, N.; Chafaa, S.; Touahria, Y. I.; Tlidjane, H. New $\alpha$-Hydrazinophosphonic acid: Synthesis, characterization, DFT study and in silico prediction of its potential inhibition of SARS-CoV-2 main protease. Journal of molecular structure 2021, $1239, \quad 130480$, https://doi.org/10.1016/j.molstruc.2021.130480.

23. Chemboli, R.; Kapavarapu, R.; Deepti, K.; Prasad, K. R. S.; Reddy, A. G.; Kumar, A. N.; Rao, M. V. B.; Pal, M. Pyrrolo [2,3-b] quinoxalines in attenuating cytokine storm in COVID-19: their sonochemical synthesis and in silico/in vitro assessment. Journal of Molecular Structure 2021, 1230, 129868, https://doi.org/10.1016/j.molstruc.2020.129868. 
24. Chhetri, A.; Chettri, S.; Rai, P.; Mishra, D. K.; Sinha, B., Brahman, D. Synthesis, characterization and computational study on potential inhibitory action of novel azo imidazole derivatives against COVID-19 main protease (Mpro: 6LU7). Journal of molecular structure 2021, 1225, 129230, https://doi.org/10.1016/j.molstruc.2020.129230.

25. Chhetri, A.; Chettri, S.; Rai, P.; Sinha, B.; Brahman, D. Exploration of inhibitory action of Azo imidazole derivatives against COVID-19 main protease (Mpro): A computational study. Journal of molecular structure 2021, 1224, 129178, https://doi.org/10.1016/j.molstruc.2020.129178.

26. Chidambaram, S.; El-Sheikh, M. A.; Alfarhan, A. H.; Radhakrishnan, S.; Akbar, I. Synthesis of novel coumarin analogues: Investigation of molecular docking interaction of SARS-CoV-2 proteins with natural and synthetic coumarin analogues and their pharmacokinetics studies. Saudi Journal of Biological Sciences 2021, 28, 1100-1108, https://doi.org/10.1016/j.sjbs.2020.11.038.

27. Domínguez-Villa, F. X.; Durán-Iturbide, N. A.; Ávila-Zárraga, J. G. Synthesis, molecular docking, and in silico ADME/Tox profiling studies of new 1-aryl-5-(3-azidopropyl) indol-4-ones: Potential inhibitors of SARS CoV-2 main protease. Bioorganic chemistry 2021, 106, 104497 , https://doi.org/10.1016/j.bioorg.2020.104497

28. Douche, D.; Sert, Y.; Brandán, S. A.; Kawther, A. A.; Bilmez, B.; Dege, N.; Louzi, A. E.; Bougrin, K.; Karrouche, K.; Himmi, B. 5-((1H-imidazol-1-yl) methyl) quinolin-8-ol as potential antiviral SARS-CoV-2 candidate: Synthesis, crystal structure, Hirshfeld surface analysis, DFT and molecular docking studies. Journal of molecular structure 2021, 1232, 130005, https://doi.org/10.1016/j.molstruc.2021.130005.

29. El Kalai, F.; Çınar, E. B.; Lai, C. H.; Daoui, S.; Chelfi, T.; Allali, M.; Dege, N.; Karrouchi, K.; Benchat, N. Synthesis, spectroscopy, crystal structure, TGA/DTA study, DFT and molecular docking investigations of (E)-4-(4-methylbenzyl)-6-styrylpyridazin-3 (2H)-one. Journal of Molecular Structure 2021, 1228, 129435, https://doi.org/10.1016/j.molstruc.2020.129435.

30. Khorsandi, Z.; Afshinpour, M.; Molaei, F.; Askandar, R. H.; Keshavarzipour, F.; Abbasi, M.; SadeghiAliabadi, H. Design and synthesis of novel phe-phe hydroxyethylene derivatives as potential coronavirus main protease inhibitors. Journal of Biomolecular Structure and Dynamics 2021, 1-9, https://doi.org/10.1080/07391102.2021.1905549.

31. Kreutzer, A. G.; Krumberger, M.; Diessner, E. M.; Parrocha, C. M. T.; Morris, M. A.; Guaglianone, G.; Butts, C. T.; Nowick, J. S. A cyclic peptide inhibitor of the SARS-CoV-2 main protease. European journal of medicinal chemistry 2021, 221, 113530, https://doi.org/10.1016/j.ejmech.2021.113530.

32. Kusumaningsih, T.; Prasetyo, W. E.; Wibowo, F. R.; \& Firdaus, M. Toward an efficient and eco-friendly route for the synthesis of dimeric 2, 4-diacetyl phloroglucinol and its potential as a SARS-CoV-2 main protease antagonist: insight from in silico studies. New Journal of Chemistry 2021, 45, 7830-7843, https://doi.org/10.1039/D0NJ06114J.

33. Lauro, F. V.; Francisco, D. C.; Marcela, R. N.; Maria, L. R.; Maria Virginia, M. A.; Alejandara, G. E.; Estrella-Barron, R.; Regina, C. C. Design and Synthesis of a Lactam-Steroid Derivative and their Theoretical Interaction with a SAR-COV2 Biointerface Research in Applied Chemistry 2021, 11, 7621-7631, https://doi.org/10.33263/BRIAC111.76217631.

34. Özkan, H.; Adem, Ş. Synthesis, Spectroscopic Characterizations of Novel Norcantharimides, Their ADME Properties and Docking Studies Against COVID-19 Mpr . ChemistrySelect 2020, 5, 5422, https://doi.org/10.1002/slct.202001123.

35. Sarfraz, M.; Rauf, A.; Keller, P.; Qureshi, A. M. N, N'-dialkyl-2-thiobarbituric acid based sulfonamides as potential SARS-CoV-2 main protease inhibitors. Canadian Journal of Chemistry 2021, 99, 330-345, https://doi.org/10.1139/cjc-2020-0332.

36. Satyanarayana, M. V.; Reddy, A. G.; Yedukondalu, M.; Tej, M. B.; Hossain, K. A.; Rao, M. V. B.; Pal, M. In silico assessment and sonochemical synthesis of 2-alkynyl 3-chloropyrazines as prospective ligands for SARS-CoV-2. Journal of molecular structure 2021, 1231, 129981 , https://doi.org/10.1016/j.molstruc.2021.129981.

37. Shahinshavali, S.; Hossain, K. A.; Kumar, A. V. D. N.; Reddy, A. G.; Kolli, D.; Nakhi, A.; Rao, M. V. B.; Pal, M. Ultrasound assisted synthesis of 3-alkynyl substituted 2-chloroquinoxaline derivatives: Their in silico assessment as potential ligands for N-protein of SARS-CoV-2. Tetrahedron letters 2020, 61, 152336, https://doi.org/10.1016/j.tetlet.2020.152336.

38. Topal, T.; Zorlu, Y.; Karapinar, N. Synthesis, X-ray crystal structure, IR and Raman spectroscopic analysis, quantum chemical computational and molecular docking studies on hydrazone-pyridine compound: As an 
insight into the inhibitor capacity of main protease of SARS-CoV2. Journal of Molecular Structure 2021, 1239, 130514, https://doi.org/10.1016/j.molstruc.2021.130514.

39. Venkateshan, M.; Suresh, J.; Muthu, M.; Kumar, R. R. Azaphenantherene derivatives as inhibitor of SARS CoV-2 Mpro: Synthesis, physicochemical, quantum chemical and molecular docking analysis. Chemical Data Collections 2020, 28, 100470, https://doi.org/10.1016/j.cdc.2020.100470.

40. Venkateshan, M.; Muthu, M.; Suresh, J.; Kumar, R. R. Azafluorene derivatives as inhibitors of SARS CoV2 RdRp: Synthesis, physicochemical, quantum chemical, modeling and molecular docking analysis. Journal of molecular structure 2020, 1220, 128471, https://doi.org/10.1016/j.molstruc.2020.128741.

41. Oliveira Carneiro Brum, J.; França, T. C.; LaPlante, S. R.; Villar, J. D. F. Synthesis and biological activity of hydrazones and derivatives: A review. Mini reviews in medicinal chemistry 2020, 20, 342-368, https://doi.org/10.2174/13895575196661910141424481.

42. Masaret, G. S. A New Approach for the Synthesis and Biological Activities of Novel Thiazolyl-Pyrazole Derivatives. ChemistrySelect 2021, 6, 974-982, https://doi.org/10.1002/slct.202004304.

43. Venkateshan, M.; Muthu, M.; Suresh, J.; Kumar, R. R. Azafluorene derivatives as inhibitors of SARS CoV2 RdRp: Synthesis, physicochemical, quantum chemical, modeling and molecular docking analysis. Journal of molecular structure 2020, 1220, 128471, https://doi.org/10.1016/j.molstruc.2020.128741.

44. Venkateshan, M.; Muthu, M.; Suresh, J.; Kumar, R. R. Azafluorene derivatives as inhibitors of SARS CoV2 RdRp: Synthesis, physicochemical, quantum chemical, modeling and molecular docking analysis. Journal of molecular structure 2020, 1220, 128471, https://doi.org/10.1016/j.molstruc.2020.128741.

45. Fairoosa, J.; Neetha, M.; Anilkumar, G. Ultrasound-assisted synthesis of heterocyclic compounds. Molecular Diversity 2020, 24, 771-820, https://doi.org/10.1007/s11030-019-09964-1.

46. Ziarani, G. M.; Gholamzadeh, P. Reviews on Biological Activity, Clinical Trial and Synthesis Progress of Small Molecules for the Treatment of COVID-19. Topics in Current Chemistry 2021, 379, 1-52, https://doi.org/10.1007/s41061-020-00318-2.

47. Porto, R. S.; Amarante, G. W.; Cavallaro, M.; Poppi, R. J.; Coelho, F. Improved catalysis of Morita-BaylisHillman reaction. The strong synergic effect using both an imidazolic ionic liquid and a temperature. Tetrahedron Letters 2009, 50, 1184-1187, https://doi.org/10.1016/j.tetlet.2008.12.089.

48. Kaur, N. Synthesis of six-and seven-membered heterocycles under ultrasound irradiation. Synthetic Communications 2018, 48, 1235-1258, https://doi.org/10.1080/00397911.2018.1434894.

49. Ghahremanzadeh, R.; Ahadi, S.; Shakibaei, G. I.; Bazgir, A. Grindstone chemistry: one-pot synthesis of spiro [diindenopyridine-indoline] triones and spiro [acenaphthylene-diindenopyridine] triones. Tetrahedron Letters 2010, 51, 499-502, https://doi.org/10.1016/j.tetlet.2009.11.041.

50. Toda, F. Solid state organic reactions. Synlett 1993, 1993, 303-312, https://doi.org/10.1055/s-1993-22441.

51. Pagadala, N. S.; Syed, K.; Tuszynski, J. Software for molecular docking: a review. Biophysical reviews 2017, 9, 91-102, https://doi.org/10.1007/s12551-016-0247-1.

52. Torres, P. H.; Sodero, A. C.; Jofily, P.; Silva-Jr, F. P. Key topics in molecular docking for drug design. International journal of molecular sciences 2019, 20, 4574, https://doi.org/10.3390/ijms20184574.

53. Kumar, V.; Dhanjal, J. K.; Kaul, S. C.; Wadhwa, R.; Sundar, D. Withanone and caffeic acid phenethyl ester are predicted to interact with main protease $\left(\mathrm{M}^{\mathrm{pro}}\right)$ of SARS-CoV-2 and inhibit its activity. Journal of Biomolecular Structure and Dynamics 2020, 1-13, https://doi.org/10.1080/07391102.2020.1772108.

54. Al-Karmalawya A. A.; Alnajjar. R.; Dahabd, M. M.; Metwalye, A. M.; Eissad, I. H. Molecular docking and dynamics simulations reveal the potential of anti-HCV drugs to inhibit COVID-19 main protease. Pharma Science 2021, 10.34172/PS.2021.3.

55. Zeng, W.; Liu, G.; Ma, H.; Zhao, D.; Yang, Y.; Liu, M.; Mohammed, A.; Zhao, C.; Yang, Y.; Xie, J.; Ding, C.; Ma, X.; Weng, J.; Gao, Y.; He, H.; Jin, T. Biochemical characterization of SARS-CoV-2 nucleocapsid protein. Biochemical and biophysical research communications 2020,527, 618-623, https://doi.org/10.1016/j.bbrc.2020.04.136.

56. Ganesan, A.; Coote, M. L.; Barakat, K. Molecular dynamics-driven drug discovery: leaping forward with confidence. Drug discovery today 2017, 22,249-269, https://doi.org/10.1016/j.drudis.2016.11.001.

57. Salmaso, V.; Moro, S. Bridging molecular docking to molecular dynamics in exploring ligand-protein recognition process: An overview. Frontiers in pharmacology 2018, 9, 923, https://doi.org/10.3389/fphar.2018.00923.

58. Daina, A.; Michielin, O.; Zoete, V. SwissADME: a free web tool to evaluate pharmacokinetics, drug-likeness and medicinal chemistry friendliness of small molecules. Scientific reports $\mathbf{2 0 1 7 ,}$ 7, 1-13. https://doi.org/10.1038/srep42717. 
59. Yang, H.; Lou, C.; Sun, L.; Li, J.; Cai, Y.; Wang, Z.; Li, W.; Liu, G.; Tang, Y. admetSAR 2.0: web-service for prediction and optimization of chemical ADMET properties. Bioinformatics 2019, 35, 1067-1069, https://doi.org/10.1093/bioinformatics/bty707.

60. Pires, D. E.; Blundell, T. L.; Ascher, D. B. pkCSM: predicting small-molecule pharmacokinetic and toxicity properties using graph-based signatures. Journal of medicinal chemistry 2015, 58, 4066-4072, https://doi.org/10.1021/acs.jmedchem.5b00104.

61. Patrick, G. L. An introduction to medicinal chemistry 2013, Oxford university press. 